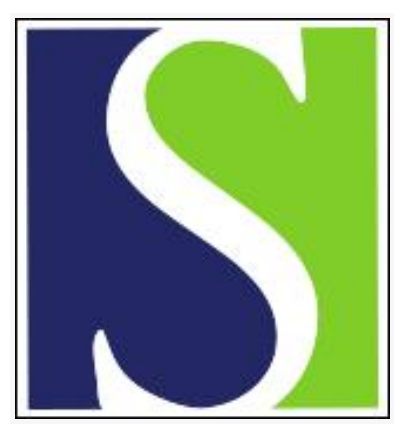

Scand J Work Environ Health 1987;13(4):305-308

https://doi.org/10.5271/sjweh.2035

Issue date: Aug 1987

Longitudinal study of vibration-induced white finger among coastal fallers in British Columbia.

by Brubaker RL, Mackenzie CJ, Hertzman C, Hutton SG, Slakov J

Affiliation: Department of Health Care and Epidemiology, University of British Columbia, Vancouver, Canada.

This article in PubMed: www.ncbi.nlm.nih.gov/pubmed/3433031 


\title{
Longitudinal study of vibration-induced white finger among coastal fallers in British Columbia
}

\author{
by Robert L Brubaker, PhD, ${ }^{1}$ Cortlandt JG Mackenzie, MD, DPH, FRCPC, ${ }^{1}$ \\ Clyde Hertzman, MD, FRCPC, ${ }^{1}$ Stanley G Hutton, PhD, ${ }^{2}$ Jody Slakov, BS ${ }^{2}$
}

\begin{abstract}
BRUBAKER RL, MACKENZIE CJG, HERTZMAN C, HUTTON SG, SLAKOV J. Longitudinal study of vibration-induced white finger among coastal fallers in British Columbia. Scand $J$ Work Environ Health 13 (1987) 305-308. Symptom-based vibration-induced white finger was determined longitudinally from a questionnaire administered to 71 full-time fallers exposed $2-4 \mathrm{~h}$ daily to generally heavy ( $>11 \mathrm{~kg}$ ), large displacement $(>95 \mathrm{cc}$ ) chain saws. The prevalence of Raynaud's phenomenon among 55 fallers (after 16 fallers were excluded because of possible confounders) was $51 \%$ in 1979-1980. This figure did not differ significantly from the prevalence in 1984-1985 (53\%). Among the 28 fallers reporting symptoms in 1979 - 1980, seven reported no symptoms in 1984-1985, while four indicated improvement in the severity of symptoms resulting in a decreased stage assessment. Evidence for actual recovery was weak because of discrepancies in the symptom reporting. Reported recovery and improvement in the group with symptoms in 1979-1980 was counterbalanced by a significant $30 \%$ onset of new symptoms among fallers who were asymptomatic in 1979-1980. Six of the eight fallers reporting new symptoms were exposed only to antivibration saws, a finding suggesting that the type of saws used in the present investigation is not preventing the onset of new disease. Weighted 4-h equivalent acceleration levels from the handlebars of saws commonly used by the cohort group in 1984 ranged from 4.0 to $12.4 \mathrm{~m} / \mathrm{s}^{2}$.
\end{abstract}

Key terms: acceleration, antivibration, chain saw.

Longitudinal studies in Great Britain (6), Finland (5), and Japan (2) have shown a significant reduction in the prevalence of symptom-based vibration-induced white finger (VWF) since the introduction of antivibration (AV) saws in the early 1970s. Chain saws typically used in these countries average $<60 \mathrm{cc}$ displacement and weigh $<7 \mathrm{~kg}$ with an average $53-\mathrm{cm}$ bar.

The primary objective of this research was to evaluate the ameliorative effect of more powerful ( $>95$ cc) and heavier AV chain saws $(>11 \mathrm{~kg}$ with an average $81-\mathrm{cm}$ bar) on VWF in the coastal area of British Columbia, where the prevalence of this disease was $54 \%$ in $1979-1980$ (1). Fallers are exposed to chain-saw vibration $2-4 \mathrm{~h}$ daily for 10 months of the year in this area, where temperatures reach a low of 0 to $5^{\circ} \mathrm{C}$ in January with average precipitation levels of $250-350 \mathrm{~cm}$ annually. A secondary objective was to measure the vibration levels of large AV saws currently used by fallers in the coastal area of British Columbia.

\footnotetext{
1 Department of Health Care and Epidemiology, The University of British Columbia, Vancouver, British Columbia, Canada.
}

2 Department of Mechanical Engineering, The University of British Columbia, Vancouver, British Columbia, Canada.

Reprint requests to: Dr RL Brubaker, Department of Health Care and Epidemiology, The University of British Columbia, James Mather Building, 5804 Fairview Crescent, Vancouver, British Columbia, V6T IW5, Canada.

\section{Methods}

A longitudinal study was initiated in 1984-1985 involving 202 fallers from 11 coastal logging camps on the Vancouver and Queen Charlotte islands. Assistance was obtained from the British Columbia Council of Forest Industries in identifying camps with similar work practices, chain saws, climate and terrain.

All fallers in each camp were invited to participate in order to reduce the chance of self-selection bias. A detailed occupational and symptom questionnaire was administered by a trained interviewer. In addition, an objective vascular test, based on reduction in digital systolic blood pressure after combined cooling $\left(10^{\circ} \mathrm{C}\right)$ and ischemia (4), was performed on the uninjured finger most symptomatic for Raynaud's phenomenon, and the results were compared with those obtained from an uncooled, asymptomatic, uninjured finger (usually the thumb). The digit systolic blood pressure was measured with a Hokanson EC-4 plethysmograph. Digit strain gauges and finger cuffs were obtained from the same manufacturer. The staging for VWF was based on subject symptomatology according to the Taylor \& Pelmear classification system (7).

Seventy-one men from the total group of 202 fallers interviewed in 1984-1985 had also been interviewed and tested in an earlier 1979-1980 survey (1). They served as the basis for the longitudinal comparisons made in this paper.

The interview questions on occupational and medical histories, as well as the specific questions on finger symptoms, were similar in both surveys.

The objective vascular test used in the 1979-1980 survey was based on delayed finger rewarming in all 10 digits after release from combined digital cooling and ischemia (1). A change in objective vascular testing in $1984-1985$ was based in part on the painful nature of the finger rewarming test.

The vibration measurements were recorded in 1984 from chain saws currently in use at the Cameron logging camp, and they are representative of saws used in the other study locations. The tests were made in accordance with ISO-DIS 5349 (3) with a Bruel \& Kjær (B \& K) triaxial accelerometer (model 4370) attached to the handle of the saw (both front and rear) via a mechanical filter (B \& K UA 0559), acceleration levels 
being recorded in the three prescribed directions. These acceleration levels were recorded on a multichannel frequencymodulated tape deck (B \& K model 7003) via a B \& K preamplifier (model 2635). The tape-recorded data were analyzed in the laboratory with a Nicolet $660 \mathrm{~A}$ spectrum analyzer. The spectra obtained were then weighted in accordance with ISO DIS-5349 (3) and expressed as a 4-h weighted acceleration level.

\section{Results}

Table 1 lists the numbers and current locations of the 71 fallers (from six of the original 11 camps) interviewed in 1979-1980 and 1984-1985. Approximately $53 \%$ of the fallers had remained working in these locations since the 1979-1980 survey and were available and agreed to be reinterviewed and retested in 1984-1985.

A comparison of subjective Raynaud's phenomenon and finger tingling or numbing during the survey period is listed in table 2 . There was no significant difference in the prevalence of Raynaud's phenomenon and finger tingling and/or numbing over the five-year period when tested with the sign test for matched pairs. The exclusion of 16 fallers with possible confounders, such as excessive hand-arm vibration exposure other than from chain saws, incomplete vibration exposure over the five-year follow-up period, and a history of known possible causes of Raynaud's disease other than vibration exposure, did not alter these results (subgroup category, table 2). Altogether, four fallers were

Table 1. Fallers interviewed in $1979-1980$ and $1984-1985$

\begin{tabular}{llll}
\hline \multirow{3}{*}{ Company } & \multicolumn{2}{c}{ Group } \\
\cline { 3 - 4 } & $\begin{array}{l}\text { Location } \\
(1984-85)\end{array}$ & $\begin{array}{c}\text { Total } \\
\text { group }\end{array}$ & $\begin{array}{c}\text { Sub- } \\
\text { group a }\end{array}$ \\
\cline { 3 - 4 } & & $\mathrm{N} \%$ & $\mathrm{~N} \%$ \\
\hline
\end{tabular}

\section{Vancouver Island}

$\begin{array}{llrrrr}\text { CIP Ltd } & \text { Gold River } & 16 & 22.5 & 14 & 25.4 \\ \text { MacMillan Bloedel Ltd } & \text { Franklin River } & 20 & 28.2 & 18 & 32.7 \\ \text { MacMillan Bloedel Ltd } & \text { Cameron } & 1 & 1.4 & 1 & 1.8 \\ \text { Western Forest Products Ltd } & \text { Holberg } & 7 & 9.9 & 3 & 5.5 \\ \text { BC Forest Products Ltd } & \text { Honey Moon } & & & & \\ & \text { Bay } & 18 & 25.3 & 12 & 21.8\end{array}$

Queen Charlotte Island

\begin{tabular}{llllll} 
Crown Forest Products Ltd & Sandspit & 9 & 12.7 & 7 & 12.7 \\
\hline
\end{tabular}

\begin{tabular}{lllll}
\hline Total & 71 & 100 & 55 & 100
\end{tabular}

a Excludes fallers with possible confounders.

b Located at Franklin River in 1979-1980.

Table 2. Prevalence of finger symptoms among the study groups in 1979-1980 and 1984-1985.

\begin{tabular}{|c|c|c|c|c|c|c|c|c|}
\hline \multirow{4}{*}{ Symptom } & \multicolumn{8}{|c|}{ Group } \\
\hline & \multicolumn{4}{|c|}{ Total group $(N=71)$} & \multicolumn{4}{|c|}{ Subgroup $^{a}(N=55)$} \\
\hline & \multicolumn{2}{|c|}{$\begin{array}{c}1979- \\
1980\end{array}$} & \multicolumn{2}{|c|}{$\begin{array}{r}1984- \\
1985\end{array}$} & \multicolumn{2}{|c|}{$\begin{array}{c}1979- \\
1980\end{array}$} & \multicolumn{2}{|c|}{$\begin{array}{r}1984- \\
1985\end{array}$} \\
\hline & $N$ & $\%$ & $N$ & $\%$ & $N$ & $\%$ & $\mathrm{~N}$ & $\%$ \\
\hline $\begin{array}{l}\text { Raynaud's phenomenon } \\
\text { Tingling and/or numbing }\end{array}$ & $\begin{array}{l}36 \\
48\end{array}$ & $\begin{array}{l}50.7 \\
67.6\end{array}$ & $\begin{array}{l}41 \\
40\end{array}$ & $\begin{array}{l}57.7 \\
56.3\end{array}$ & $\begin{array}{l}28 \\
36\end{array}$ & $\begin{array}{l}50.9 \\
65.5\end{array}$ & & $\begin{array}{l}52.7 \\
56.4\end{array}$ \\
\hline
\end{tabular}

excluded for a history of hypertension, two for a childhood history of polio, one for arthritis of the fingers, three for cervical spine injury requiring fusion, one for Dupuytren's contracture, three for excessive vibration exposure from hobby tools ( $>10 \mathrm{~h}$ per week), and two for discontinuing falling during part of the five-year period. There were no obvious cases of primary Raynaud's disease. In addition, exclusions were not specifically made for hand-arm injury, since the prevalence of this condition is high in this occupational group (1).

Most of the results are presented only for the subgroup $(N=55)$ category after exclusions were made for possible confounders.

\section{Fallers with vibration-induced white finger} in $1979-1980$

Among 28 fallers reporting Raynaud's phenomenon in 1979-1980, four $(14 \%)$ reported a decrease in the severity of symptoms resulting in a decreased stage assignment in 1984-1985 [90\% confidence interval $(90 \% \mathrm{CI}) 3.4-25.2$ ]. In addition, seven fallers no longer reported symptoms in 1984-1985. While this change would appear to represent a possible $25 \%$ recovery rate $(90 \% \mathrm{CI} 11.5-38.5)$ over the five-year period, closer scrutiny of the seven "recovered" cases indicated the following discrepancies: (i) three fallers reporting symptoms in 1979-1980 reported never having symptoms in 1984-1985, (ii) one faller reported the disappearance of symptoms due to faith healing yet had physical evidence of disease at the time of the interview, (iii) one faller reported symptoms in 1979-1980 but in 1984-1985 reported that his last symptoms occurred in 1973, and (iv) three fallers (including the faller who had been faith-healed) reported no symptoms in 1984-1985 but had had symptoms during the preceding year.

\section{Fallers without vibration-induced white finger in 1979-1980}

Among 27 fallers not reporting symptoms in $1979-1980$, eight reported symptoms in 1984-1985. This increase represents a $30 \%$ onset of disease $(90 \%$ CI 15.1-44.1) over the five-year period. Evidence for the onset of VWF was clear-cut in four of the eight new cases. However, three fallers indicating new symptoms had in fact reported symptoms prior to 1979-1980 but were asymptomatic in $1979-1980$. A fourth faller was unsure whether symptoms were present or absent in 1984-1985.

\section{Operators of both antivibration and nonantivibration chain saws or antivibration saws only}

Approximately $33 \%$ of the fallers in this study indicated they had used only AV-type saws. The prevalence and symptomatic stages of VWF among fallers 
who used non-AV + AV, as well as AV only, saws is shown in table 3 .

Operators of both antivibration and nonantivibration chain saws. Among the group of operators who had used both AV and non-AV chain saws, the situation was somewhat reversed with an $11 \%$ decline in overall symptom prevalence, from $54 \%$ in $1979-1980$ to $43 \%$ in $1984-1985$. Decreases were noted mainly for stage 1 and stage 3 symptoms. Six of 20 fallers reporting symptoms in 1979-1980 "recovered," three improved, nine reported no change, and two actually reported a worsening of symptoms over the five-year span. Only two of 17 operators of non-AV + AV saws who were symptom negative in 1979-1980 reported new symptoms in 1984-1985 (mean onset $11.8 \%$, $90 \%$ CI $-1.1-24.7 \%)$.

Operators of antivibration chain saws only. Overall, there was a $28 \%$ increase in the prevalence of VWF in the group of operators who had used only AV chain saws during the five-year interval. The increases were not confined to stage 1 ; three more individuals reported symptoms classified as stage 3 as well. Among 10 operators of AV saws who were symptom negative in $1979-1980$, six reported the onset of symptoms in $1984-1985$ (90\% CI 34.4-85.6 \%). Among eight operators of AV saws who were symptom positive in 1979-1980, one improved, one recovered, four reported no change, and two reported deterioration.

\section{Objective testing}

The correlation of the objective test results with the symptoms is shown in table 4 . Given the fact that the two tests involved different techniques and methods of measurement, only $68 \%$ of those reporting symptoms in 1979-1980 and 54\% reporting symptoms in $1984-1985$ had positive test results. There was also poor agreement of test results with symptomatology among the subjects who reported no symptoms during both survey periods, such that the test was little better than random in testing people with symptoms.

\section{Chain-saw vibration testing}

Test results for the two chain saws most commonly used for coastal falling in British Columbia are shown in table 5. All the tests were made with a bucking cut on the same log by the same operator. Each value quoted was derived from 50 averages taken during one cut to obtain the spectrum from which the weighted levels were calculated. The results are indicated for both the front and rear handles and the levels indicated were those corresponding to the direction of maximum vibration. As noted, the acceleration levels ranged from 4.0 to $12.4 \mathrm{~m} / \mathrm{s}^{2}$. A typical spectrum is shown in figure 1 (manufacturer $\mathrm{B}$, front handle).

\section{Discussion}

This longitudinal follow-up of VWF using symptom history as a means of temporal assessment is complicated by the following factors: the unreliability of symptom reporting, the fluctuating course of the

Table 3. Distribution of symptomatic stages among operators of both nonantivibration (Non-AV) and antivibration (AV) chain saws and those using only AV saws.

\begin{tabular}{|c|c|c|c|c|c|c|c|c|}
\hline \multirow{3}{*}{ Stage } & \multicolumn{4}{|c|}{$\begin{array}{c}\text { Non-AV + AV } \\
\text { operators }\end{array}$} & \multicolumn{4}{|c|}{$\begin{array}{l}\text { AV only } \\
\text { operators }\end{array}$} \\
\hline & \multicolumn{2}{|c|}{$\begin{array}{c}1979- \\
1980\end{array}$} & \multicolumn{2}{|c|}{$\begin{array}{c}1984- \\
1985\end{array}$} & \multicolumn{2}{|c|}{$\begin{array}{c}1979- \\
1980\end{array}$} & \multicolumn{2}{|c|}{$\begin{array}{c}1984- \\
1985\end{array}$} \\
\hline & $N$ & $\%$ & $N$ & $\%$ & $N$ & $\%$ & $\mathrm{~N}$ & $\%$ \\
\hline $\begin{array}{l}0 \\
1 \\
2 \\
3\end{array}$ & $\begin{array}{r}17 \\
3 \\
9 \\
8\end{array}$ & $\begin{array}{r}45.9 \\
8.1 \\
24.3 \\
21.6\end{array}$ & $\begin{array}{r}21 \\
2 \\
10 \\
4\end{array}$ & $\begin{array}{r}56.8 \\
5.4 \\
27.0 \\
10.8\end{array}$ & $\begin{array}{r}10 \\
2 \\
5 \\
1\end{array}$ & $\begin{array}{r}55.6 \\
11.1 \\
27.8 \\
5.6\end{array}$ & $\begin{array}{l}5 \\
4 \\
5 \\
4\end{array}$ & $\begin{array}{l}27.8 \\
22.2 \\
27.8 \\
22.2\end{array}$ \\
\hline Total & 37 & 100 & 37 & 100 & 18 & 100 & 18 & 100 \\
\hline
\end{tabular}

Table 4. Comparison of objective test results with symptomatology.

\begin{tabular}{|c|c|c|c|c|}
\hline \multirow{3}{*}{ Objective test } & \multicolumn{4}{|c|}{ Raynaud's phenomenon } \\
\hline & \multicolumn{2}{|c|}{ Present } & \multicolumn{2}{|c|}{ Absent } \\
\hline & $N$ & $\%$ & $N$ & $\%$ \\
\hline \multicolumn{5}{|l|}{$1979-1980$} \\
\hline Positive ${ }^{a}$ & 19 & 67.9 & 9 & 33.3 \\
\hline Negative & 9 & 32.1 & 14 & 66.7 \\
\hline Total & 28 & 100 & 27 & 100 \\
\hline \multicolumn{5}{|l|}{$1984-1985^{\prime \prime}$} \\
\hline Positive $^{c}$ & 15 & 53.6 & 12 & 46.2 \\
\hline Negative & 13 & 46.4 & 14 & 53.8 \\
\hline Total & 28 & 100 & 26 & 100 \\
\hline
\end{tabular}

a $1-10$ digits failed to rewarm $0.2^{\circ} \mathrm{C}, 3 \mathrm{~min}$ after release from ischemia.

b Data missing for one objective test in 1984-1985.

C FSP $\%_{10} \mathrm{C}=<75$.

Table 5. Weighted acceleration levels $\left(\mathrm{m} / \mathrm{s}^{2}\right)$ recorded at Cameron Camp. (ISO = International Organization for Standardization)

\begin{tabular}{|c|c|c|}
\hline & $\begin{array}{c}\text { Front } \\
\text { handle }^{a}\end{array}$ & $\begin{array}{c}\text { Rear } \\
\text { handle }^{b}\end{array}$ \\
\hline $\begin{array}{l}\text { Manufacturer A } \\
\text { (skiptooth type of saw, } \\
\text { bar length } 36 \text { inches }(91.4 \mathrm{~cm}) \text {, } \\
\text { displacement } 99 \mathrm{cc} \text { ) }\end{array}$ & $\begin{array}{l}\text { Not } \\
\text { recorded }\end{array}$ & $\begin{array}{r}9.1 \\
12.1\end{array}$ \\
\hline $\begin{array}{l}\text { Manufacturer B } \\
\text { Saw } 1 \text { [skiptooth type of } \\
\text { saw, bar length } 33 \text { inches }(83.8 \mathrm{~cm}) \text {, } \\
\text { displacement } 95 \mathrm{cc} \text { ] }\end{array}$ & $\begin{array}{l}12.4 \\
12.1 \\
10.0\end{array}$ & $\begin{array}{r}10.6 \\
7.5 \\
7.3\end{array}$ \\
\hline $\begin{array}{l}\text { Saw } 2 \text { [skiptooth type of } \\
\text { saw, bar length } 33 \text { inches }(83.8 \mathrm{~cm}) \text {, } \\
\text { displacement } 95 \mathrm{cc} \text { ] }\end{array}$ & $\begin{array}{l}6.2 \\
4.0 \\
4.9\end{array}$ & $\begin{array}{l}7.6 \\
7.2 \\
7.1\end{array}$ \\
\hline
\end{tabular}




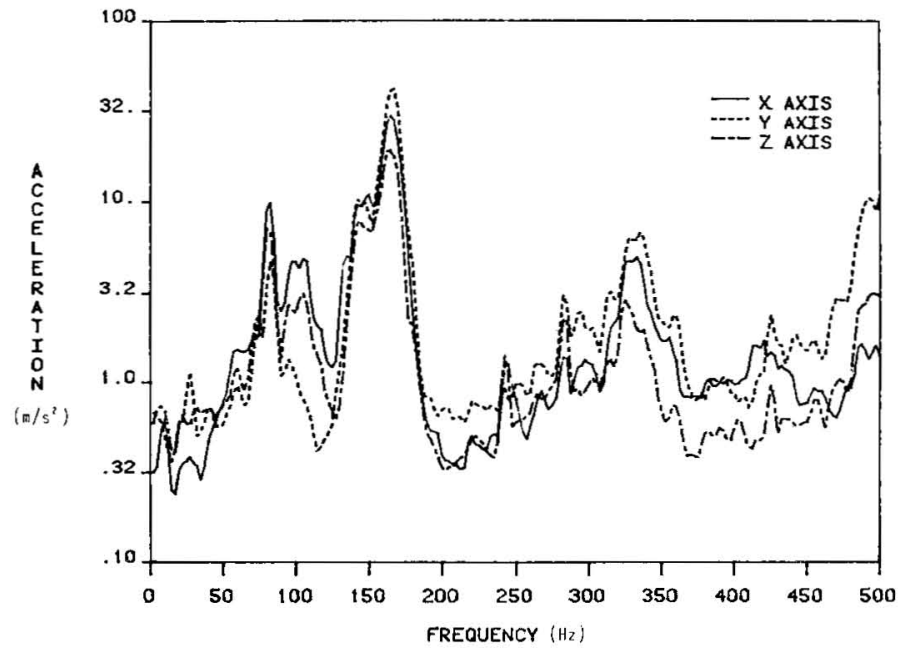

Figure 1. Typical root-mean-square acceleration spectra for the front handle of a large antivibration chain saw. disease, and the lack of agreement between symptom reporting and objective assessment. In addition there are other important confounders, as described by Riddle \& Taylor (6), such as changes in life-style or work practices and symptom learning, which can lead to an under- or overestimation of symptoms.

Despite these constraints, it appears that the use of large AV saws is not preventing the onset of new cases of VWF among coastal fallers in British Columbia. In fact, $72 \%$ of the workers exposed only to AV saws in this study developed VWF within a relatively short latency period of 4.2 (SD 2.3) years. Based on nomogram predictions made according to ISO-DIS 5349 (3). the large AV chain saws currently used by coastal fallers in British Columbia might be expected to lead to the onset of new symptoms for $50 \%$ of new users within 5-11 years. This estimate was based on vibration levels of $7-12.4 \mathrm{~m} / \mathrm{s}^{2}$ (recorded from the handle exhibiting the highest vibration) from the two commonly used chain saws field tested in this study.

A significant onset of new disease was not observed within the five-year period however among operators originally exposed to non-AV saws, a finding suggesting that a plateau may have been reached. In fact there is some evidence indicating a slight improvement (15\%) or lessening of symptoms for fallers in this group. Evidence for actual recovery from symptoms is weak because of discrepancies in the symptom reporting. It is hoped that the additional serial measure- ments now being obtained on an annual basis may help clarify symptom trends for the non-AV + AV group.

\section{References}

1. Brubaker RL, Mackenzie CJG, Eng PR, Bates DV. Vibration white finger disease among tree fellers in British Columbia. J Occup Med 25 (1983) 403-408.

2. Futatsuka M, Ueno T. Vibration exposure and vibrationinduced white finger due to chain saw operation. J Occup Med 27 (1985) 257-264.

3. International Organization for Standardization. Guidelines for the measurement and the assessment of human exposure to hand-transmitted vibration. Geneva 1984. (ISO/DIS 5349.2-1984).

4. Nielsen SL, Lassen MA. Measurement of digital blood pressure after local cooling. J Appl Physiol 43 (1977) 907-910.

5. Pyykkö I, Korhonen OS, Färkkilä MA, Starck JP, Aatola SA. A longitudinal study of vibration syndrome in Finnish forestry workers. In: Brammer AJ, Taylor $W$, ed. Vibration effects on the hand and arm in industry. John Wiley \& Sons, New York, NY 1982, pp $157-162$.

6. Riddle HFV, Taylor W. Vibration-induced white finger among chain sawers nine years after the introduction of anti-vibration measures. In: Brammer AJ, Taylor W, ed. Vibration effects on the hand and arm in industry. John Wiley \& Sons, New York, NY 1982, pp 169-173.

7. Taylor W, Pelmear PL, Pearson J. Raynaud's phenomenon in forestry chain saw operators. In: Taylor W, ed. The vibration syndrome. Academic Press, London 1974, pp $121-139$. 